\title{
Prediction of zinc deficiency in navy beans (Phaseolus vulgaris) by soil and plant analyses
}

\author{
J.D.Armour , A.D.Robson , G.S.P.Ritchie
}

Summary. Navy beans (Phaseolus vulgaris cv. Gallaroy) were grown with 7 rates of zinc $(\mathrm{Zn})$ in a Zn-deficient gravelly sandy loam in a glasshouse experiment. The plant shoots were harvested 31 days after sowing and the $\mathrm{Zn}$ concentration in each of 4 plant parts (YL, young leaf; YOL, young open leaf; YFEL, youngest fully expanded leaf; and whole shoots) was related to the fresh weight of the shoots. The critical $\mathrm{Zn}$ concentrations $(\mathrm{mg} / \mathrm{kg}$ ) in the plant parts determined by the 2 intersecting straight lines model were 21.1 for $Y L$ $\left(r^{2}=0.66\right), 17.1$ for YOL $\left(r^{2}=0.83\right), 10.6$ for YFEL $\left(r^{2}=0.91\right)$ and 12.5 for the whole tops $\left(r^{2}=0.88\right)$. The YFEL was selected as an appropriate diagnostic tissue because it is readily identifiable in the field and had the highest $r^{2}$ with fresh weight.

In a second glasshouse experiment, the critical $\mathrm{Zn}$ concentration in the YFEL and 5 soil tests were evaluated for their ability to predict the $\mathrm{Zn}$ status of navy beans. There were 13 soils from sands to clays with a wide range of chemical properties. The soil tests were $0.1 \mathrm{~mol} / \mathrm{L} \mathrm{HCl}, \mathrm{DTPA}$, EDTA, dilute $\mathrm{CaCl}_{2}$ and

\section{Introduction}

Navy beans (Phaseolus vulgaris) are very sensitive to zinc (Zn) deficiency (Viets et al. 1954; Moraghan 1984), which decreases crop yield and the concentration of $\mathrm{Zn}$ in seeds and delays crop maturity (Boawn et al. 1969; Brouwer et al. 1981). Response of navy beans to $\mathrm{Zn}$ fertiliser in Australia has been measured or observed on a range of soils from granitic sands to krasnozems and black earths (Wade and Bath 1985; Armour et al. 1989).

Whilst soil and plant analyses have both been used to predict the likelihood of a response to $\mathrm{Zn}$ fertilisation, soil analysis before sowing has the advantage of allowing for $\mathrm{Zn}$ application at sowing or early in the life of the crop to prevent yield loss. Because extractants for estimating the amount of soil $\mathrm{Zn}$ available to plants have generally been satisfactory only for a limited range of soil types, the use of soil tests for predictive purposes is usually confined to the soil types on which the test was developed (Cox and Kamprath 1972). The most commonly used soil tests are those that measure the soil solution $\mathrm{Zn}$. The concentration of $\mathrm{Zn}$ in the YFEL correctly predicted $\mathrm{Zn}$ deficiency or adequacy in about $77 \%$ of samples. The results from both experiments showed that a critical $\mathrm{Zn}$ concentration of $10-11 \mathrm{mg} / \mathrm{kg}$ in the YFEL can be used to diagnose the $\mathrm{Zn}$ status of Gallaroy navy beans.

It was not possible to recommend a single soil test for prediction of the relative yield of navy beans. A combination of quantity ( $\mathrm{HCl}, \mathrm{EDTA}, \mathrm{DTPA})$ and intensity (soil solution, $0.002 \mathrm{~mol} / \mathrm{L} \mathrm{CaCl} 2,0.01 \mathrm{~mol} / \mathrm{L}$ $\mathrm{CaCl}_{2}$ ) parameters were able to explain most of the variation in the $\mathrm{Zn}$ concentration of the YFEL, a more sensitive measure of nutrient availability than relative yield. EDTA- $\mathrm{Zn}$ in combination with $0.01 \mathrm{~mol} / \mathrm{L} \mathrm{CaCl} 2-\mathrm{Zn}$ explained $90 \%$ of the variation in the $\mathrm{Zn}$ concentration in the YFEL, while $\mathrm{HCl}$ - or DTPA-Zn and $0.01 \mathrm{~mol} / \mathrm{L} \mathrm{CaCl}_{2}$ explained about $80 \%$ of the variation. As soil solution $\mathrm{Zn}$ was significantly correlated with 0.002 and $0.01 \mathrm{~mol} / \mathrm{L}$ $\mathrm{CaCl}_{2}-\mathrm{Zn}(r=0.75, P<0.01 ; r=0.62, P<0.05$, respectively), $\mathrm{CaCl}_{2}-\mathrm{Zn}$ may be used as a more convenient measure of $\mathrm{Zn}$ intensity than soil solution $\mathrm{Zn}$. quantity component of soil $\mathrm{Zn}$ by having a high ionic strength in comparison to soil solution or a wide soil/solution ratio (e.g. DTPA and $0.1 \mathrm{~mol} / \mathrm{L} \mathrm{HCl}$ ). However, both Tiller et al. (1972) and McGrath et al. (1985) concluded that intensity measurements appear to be more suitable than quantity measurements for the prediction of deficiency across a range of soil types. Consideration of both quantity and intensity may allow soil tests for $\mathrm{Zn}$ to be used over a wider range of soil types. Calibration of soil tests with navy bean growth does not appear to have been reported.

The analysis of plant parts has been shown to be suitable for prediction of $\mathrm{Zn}$ deficiency over a range of soils (Brennan 1990). Reuter et al. (1982) found that samples of composite plant parts were unsuitable for diagnosis of $\mathrm{Zn}$ deficiency in subterranean clover because there were complex relationships between dry matter yield, $\mathrm{Zn}$ concentration, time of harvest and $\mathrm{Zn}$ supply. They recommended the use of a single plant part of defined physiological age for diagnosis of $\mathrm{Zn}$ 
deficiency (e.g. youngest open blade for subterranean clover). The main limitation of plant analysis is the short period available for the diagnosis and correction of the deficiency before serious yield loss occurs.

Data on $\mathrm{Zn}$ concentrations in shoots of navy beans are limited. Zinc concentration has been measured in whole shoots of navy beans (Moraghan 1984; Leggett and Westermann 1986) and in plant parts of navy beans (Mugwira and Knezek 1971) and red Mexican beans (Phaseolus vulgaris) (Viets et al. 1954). However, Zn concentrations in a suitable plant part of navy beans have not been related to plant growth or yield to determine critical concentrations.

We evaluated 5 plant parts of navy beans for suitability as diagnostic tissue, and 6 soil tests for their ability to predict the responsiveness of navy beans to $\mathrm{Zn}$.

\section{Materials and methods}

An initial experiment was conducted to determine the most appropriate plant tissue, and its critical $\mathrm{Zn}$ concentration, for prediction of growth responses of navy beans to applied $\mathrm{Zn}$. A second experiment assessed the ability of soil tests to predict responsiveness to $\mathrm{Zn}$ application and the usefulness of the optimum plant tissue concentration previously defined.

Experiment 1. Determination of diagnostic tissue for $\mathrm{Zn}$ and critical $Z n$ concentration for navy beans

Fresh weight and $\mathrm{Zn}$ concentration of shoots were measured in navy beans grown in a sandy gravelly loam from Talbot (Table 1) with $\mathrm{Zn}$ supply varying from very deficient to adequate. Seven rates of $\mathrm{Zn}$ as $\mathrm{ZnSO}_{4} .7 \mathrm{H}_{2} \mathrm{O}$ $(0,0.25,0.5,1.0,1.5,2.0$ and $2.5 \mathrm{mg} \mathrm{Zn} / \mathrm{kg}$ oven-dry soil $)$ were applied and there were 3 replicates. General glasshouse procedures have been described previously (Armour et al. 1989). Navy beans were grown in $2490 \mathrm{~g}$ of oven-dry soil in root-cooling tanks at $25^{\circ} \mathrm{C}$. After surface application of solutions of $\mathrm{Zn}$ and basal nutrients, the soil was allowed to dry and was mixed. Phaseolus vulgaris cv. Gallaroy was sown in May 1988 and the shoots were harvested when flower buds were forming 31 days after sowing (DAS). After weighing, the shoots were sectioned into young leaf (YL), young open leaf (YOL), youngest fully expanded leaf (YFEL) and remainder. $\mathrm{Zn}$ concentration in each plant part was determined by flame atomic absorption (Allan 1961) after digestion in $\mathrm{HClO}_{4} / \mathrm{H}_{2} \mathrm{SO}_{4}$ (Johnson and Ulrich 1959).

The infectivity of vesicular arbuscular mycorrhizal fungi in roots was determined in each treatment after harvest by the method of Abbott and Robson (1981).

\section{Experiment 2. Prediction of $Z n$ deficiency in navy beans} by soil and plant analysis

Navy beans were grown in an experiment with a complete factorial of 13 soils, 3 rates of $\mathrm{Zn}$ and 3 replications.

Soils ranging from $\mathrm{Zn}$-deficient to $\mathrm{Zn}$-adequate $(0-10 \mathrm{~cm})$ from south-western Western Australia and Queensland were used (Table 1). The Western Australian soils and soil 8 were virgin soils, while the other Queensland soils had been used for more than 20 years for cropping (soils $10,11,12,13$ ) or for permanent introduced pasture (soil 9) without $\mathrm{Zn}$ fertiliser. The soils were dried and sieved to $<4 \mathrm{~mm}$ (Western Australia) or $<10 \mathrm{~mm}$ (Queensland).

Table 1. Some soil properties $(0-10 \mathrm{~cm})$ on an air-dry basis and rates of application of $\mathrm{Zn}$ and $\mathrm{P}$ in experiment 2

\begin{tabular}{|c|c|c|c|c|c|c|c|c|c|c|}
\hline \multirow[t]{2}{*}{ Soil } & \multirow[t]{2}{*}{ Location } & \multirow[t]{2}{*}{ Classification $^{A}$} & \multirow[t]{2}{*}{$\begin{array}{c}\mathrm{pH} \\
\left(1: 5, \mathrm{H}_{2} \mathrm{O}\right)\end{array}$} & \multirow[t]{2}{*}{$\begin{array}{l}\text { Organic C } \\
\qquad \%)\end{array}$} & \multirow[t]{2}{*}{$\begin{array}{c}\text { ECEC } \\
(\mathrm{cmol}(+) / \mathrm{kg})\end{array}$} & \multirow{2}{*}{$\begin{array}{c}\text { Soil } \\
\text { weight } \\
\text { (g/pot) }\end{array}$} & \multirow{2}{*}{$\begin{array}{c}\text { Field } \\
\text { capacity } \\
(\%)\end{array}$} & \multicolumn{2}{|c|}{$\begin{array}{l}\mathrm{Zn} \text { rate } \\
\text { (mg/pot) }\end{array}$} & \multirow[t]{2}{*}{$\begin{array}{l}\text { P rate } \\
\text { (mg/pot) }\end{array}$} \\
\hline & & & & & & & & $\mathrm{Zn}_{1}$ & $\mathrm{Zn}_{2}$ & \\
\hline \multicolumn{11}{|c|}{ Westem Australia } \\
\hline 1 & Talbot & Dy 3.81 & 5.7 & 3.0 & 7.24 & 2500 & 25 & 1.8 & 3.6 & 600 \\
\hline 2 & Wongan Hills & Uc 5.22 & 5.5 & 0.6 & 0.91 & 3200 & 13 & 1.8 & 3.6 & 250 \\
\hline 3 & Dandaragan & Uc 5.21 & 6.2 & 0.5 & 4.46 & 3300 & 16 & 1.8 & 3.6 & 600 \\
\hline 4 & Wongan Hills & Uc 5.22 & 5.4 & 0.5 & 0.67 & 3300 & 11 & 1.8 & 3.6 & 300 \\
\hline 5 & Merredin & Dr 2.33 & 7.1 & 1.6 & 8.21 & 2800 & 23 & 1.8 & 3.6 & 600 \\
\hline 6 & Badgingarra & Uc 5.11 & 5.5 & 0.5 & 1.25 & 3000 & 17 & 1.4 & 2.8 & 250 \\
\hline 7 & Nannup & Dy 3.61 & 5.7 & 1.2 & 1.44 & 2800 & 28 & 1.4 & 2.8 & 600 \\
\hline \multicolumn{11}{|c|}{ Queensland } \\
\hline 8 & Mt Garnet & Dy 5.81 & 6.3 & 1.3 & 5.00 & 3300 & 19 & 5 & 10 & 600 \\
\hline 9 & Murray Upper & $\mathrm{Gn} 2.21$ & 5.3 & 1.9 & 6.82 & 2300 & 28 & 5 & 10 & 800 \\
\hline 10 & Tolga & Gn 3.11 & 5.6 & 1.7 & 8.18 & 2300 & 38 & 5 & 10 & 1200 \\
\hline 11 & Evelyn & Gn 3.74 & 4.9 & 4.4 & 4.37 & 2300 & 43 & 5 & 10 & 2000 \\
\hline 12 & Upper Barron & Gn 3.11 & 5.7 & 3.9 & 10.06 & 2300 & 44 & 5 & 10 & 1200 \\
\hline 13 & Emerald & Ug 5.12 & 6.9 & 1.3 & 64.4 & 2300 & 54 & 26 & 52 & 400 \\
\hline
\end{tabular}

A Northcote (1971). 
Soils 6 and 7 were incubated after a $\mathrm{Zn}$ application of $1 \mathrm{mg} /$ pot (before the addition of $\mathrm{Zn}$ rates defined in Table 1), with the aim of producing only a moderate response to subsequent $\mathrm{Zn}$ application in light-textured soils. $\mathrm{Zn}$ was added in solution as $\mathrm{ZnSO}_{4} .7 \mathrm{H}_{2} \mathrm{O}$ to the soil surface, mixed after drying and repotted. The soils were watered to $75 \%$ of field capacity, sealed with plastic bags and incubated in a glasshouse at $30^{\circ} \mathrm{C}$ for 4 days. The soils were dried on polythene sheeting in a glasshouse, mixed and repotted and then treated as for the remainder of the soils.

Glasshouse procedures were the same as in experiment 1 , except for applied nutrient treatments. Rates of $\mathrm{Zn}$ (designated $\mathrm{Zn}_{0}, \mathrm{Zn}_{1}, \mathrm{Zn}_{2}$ ) varied with soil type (Table 1). Phosphorus was supplied as $\mathrm{KH}_{2} \mathrm{PO}_{4}$ for rates of application of $<800 \mathrm{mg} /$ pot, or as equal amounts of $\mathrm{KH}_{2} \mathrm{PO}_{4}$ and $\mathrm{NaH}_{2} \mathrm{PO}_{4}$ for rates $>800 \mathrm{mg} \mathrm{P} /$ pot. $\mathrm{MgSO}_{4} .7 \mathrm{H}_{2} \mathrm{O}$ was applied at $150 \mathrm{mg} /$ pot and $\mathrm{H}_{3} \mathrm{BO}_{3}$ at $2 \mathrm{mg} /$ pot.

Soil samples were taken from each pot after addition of nutrients and mixing, and sieved to $<2 \mathrm{~mm}$. Seeds were sown in December 1987 and the plants were harvested 22 DAS when flower buds were forming. Samples of YFEL taken at harvest were analysed for $\mathrm{Zn}$ content. Relative yield (RY) of shoots was calculated as the yield for each $\mathrm{Zn}$ rate divided by the maximum yield for each soil.

The methods used for $\mathrm{Zn}$ analysis of soil were: (i) $0.1 \mathrm{~mol} / \mathrm{L} \mathrm{HCl}$ (Tiller et al. 1972; $30 \mathrm{~min}$ shake at soil/solution ratio of 1:20); (ii) $0.005 \mathrm{~mol} / \mathrm{L}$ EDTA and $0.01 \mathrm{~mol} / \mathrm{L} \mathrm{Ca}\left(\mathrm{NO}_{3}\right)_{2}$ (Fujii and Corey 1986); (iii) $0.005 \mathrm{~mol} / \mathrm{L}$ DTPA (Lindsay and Norvell 1978); (iv) $0.01 \mathrm{~mol} / \mathrm{L} \mathrm{CaCl}$; (v) $0.002 \mathrm{~mol} / \mathrm{L} \mathrm{CaCl}$; (vi) soil solution. Samples for methods (iv) and (v) were shaken for $16 \mathrm{~h}$ at a soil/solution ratio of $1: 5$. The $\mathrm{CaCl}_{2}$ extracting solutions were prepared from a stock solution that had been purified with dithizone/chloroform (Hewitt 1952). Soil solution extracts were obtained with a centrifugation technique (Aitken and Outhwaite 1987). After centrifugation, all extracts were filtered $\left(<0.45 \mu \mathrm{m} ; \mathrm{CaCl}_{2}\right.$ and soil solution extracts were acidified to $0.1 \mathrm{~mol} / \mathrm{L}$ with $\mathrm{HCl}$ ) and analysed by flame atomic absorption. Flameless atomic absorption was used when $\mathrm{Zn}$ concentrations were less than $0.1 \mathrm{mg} / \mathrm{L}$.

An index of buffer capacity $(\mathrm{BCl})$ was calculated for each soil as $\mathrm{Q} / \mathrm{I}$ where $\mathrm{Q}$ was estimated by $\mathrm{HCl}$ extractable $\mathrm{Zn}$, and I was estimated by the soil solution $\mathrm{Zn}$ concentration.

Roots from 1 replicate of each treatment in each soil were examined for infection by VA mycorrhizal fungi by the method described for experiment 1, to ensure that responses to $\mathrm{Zn}$ were not confounded by different rates of mycorrhizal infectivity in the soils.

\section{Statistical methods}

A Mitscherlich equation was used to describe the

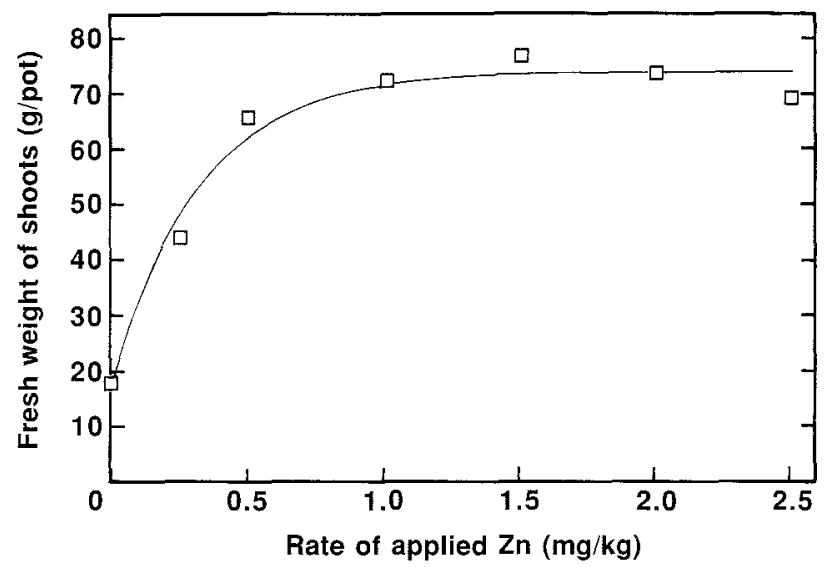

Fig. 1. Experiment 1. The relationship (and fitted Mitscherlich equation) between fresh weight of navy bean shoots and rate of applied $\mathrm{Zn}$. The equation of the line is: $Y=73.99-56.96 \mathrm{e}^{-3.14 x}\left(r^{2}=0.94\right)$.

relationship between fresh weight of shoots and the rate of applied $\mathrm{Zn}$ in experiment 1 . For experiment 2 , the 2 intersecting straight lines model (Griffiths and Miller 1973) was used to describe the relationships between fresh weight of shoots and relative yield and $\mathrm{Zn}$ concentration in the YFEL. Zn concentration in the YFEL in experiment 2 was related to measures of quantity, buffer capacity and intensity in the soils with multiple linear regression.

\section{Results}

Experiment 1. Determination of diagnostic tissue for $\mathrm{Zn}$ and critical $Z n$ concentrations for navy beans

Deficiency symptoms. Symptoms of $\mathrm{Zn}$ deficiency appeared at 18 DAS and were similar to those described previously (Armour et al. 1989) although red veination was not as obvious in this experiment. At harvest, severe $\mathrm{Zn}$ deficiency symptoms (stunting, red veination and large necrotic patches on the primary leaves, and faint interveinal chlorosis of the first and second trifoliate leaves) were observed on the nil $\mathrm{Zn}$ plants. The symptoms reduced in severity as the $\mathrm{Zn}$ rate increased to $1 \mathrm{mg} / \mathrm{kg}$ soil. Plants from this treatment had no symptoms, apart from a slight reduction in the growth of shoots, and there were no symptoms at higher application rates.

Fresh weight and $Z n$ concentration of shoots. The application of $\mathrm{Zn}$ increased fresh weight of navy bean shoots to a maximum of about $77 \mathrm{~g} /$ pot for a $\mathrm{Zn}$ application of $1.5 \mathrm{mg} / \mathrm{kg}$ soil (Fig. 1). The response curve was well described by a Mitscherlich function. Fresh weight of the plants that received no $\mathrm{Zn}$ was $24 \%$ of the maximum yield defined by the Mitscherlich function. Infection by VA myccorhizal fungi was too low $(<16 \%)$ to affect nutrient uptake (Abbott and 


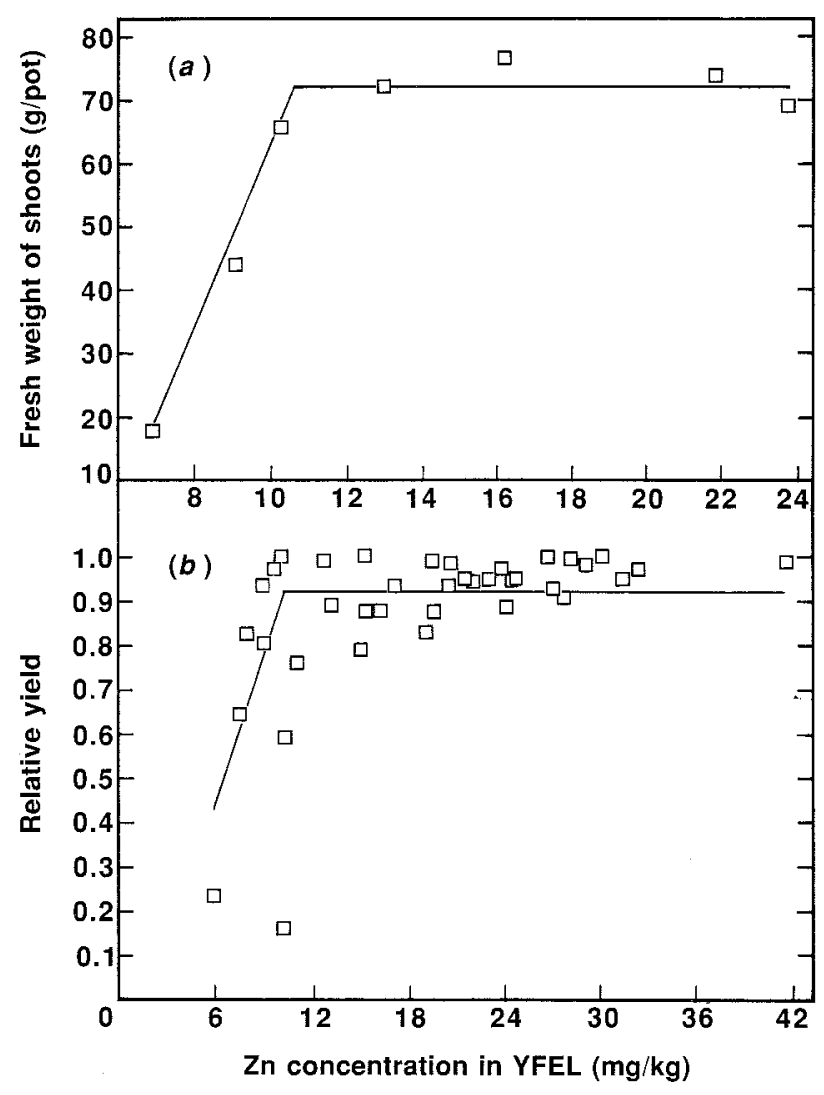

Fig. 2. The relationship between ( $a$ ) fresh weight of navy bean shoots (experiment 1) or (b) relative yield of navy bean shoots for $\mathrm{Zn}_{0}, \mathrm{Zn}_{1}$, and $\mathrm{Zn}_{2}$ treatments (experiment 2 ) and $\mathrm{Zn}$ concentration in YFEL, and the fitted two intersecting straight lines model. The critical $\mathrm{Zn}$ concentrations from the models are $(a) 10.6\left(r^{2}=0.91\right)$ and $(b) 10.1$ $\left(r^{2}=0.33\right) \mathrm{mg} / \mathrm{kg}$.

Robson 1981) and not related to rate of $\mathrm{Zn}$ application.

The $\mathrm{Zn}$ concentrations in each of the plant parts increased with rate of $\mathrm{Zn}$ application up to $0.5-1 \mathrm{mg} / \mathrm{kg}$ (Fig. $2 a$, only YFEL data presented). The critical $\mathrm{Zn}$ concentrations (and standard errors) in $\mathrm{mg} / \mathrm{kg}$ determined by the 2 intersecting straight lines model were $21.1(0.1)$ for $\mathrm{YL}, 17.1$ (1.4) for YOL, $10.6(0.4)$ for YFEL and $12.5(0.3)$ for whole tops. The $r^{2}$ for the respective plant parts were $0.66,0.83,0.91$ and 0.88 $(P<0.01)$. YFEL was selected as an appropriate diagnostic tissue because it is readily identifiable in the field and had the highest coefficient of determination with fresh weight.

Experiment 2. Prediction of $Z$ n deficiency in navy beans by soil and plant analysis.

Deficiency symptoms. Zn deficiency symptoms began to appear in $\mathrm{Zn}_{0}$ plants at $10 \mathrm{DAS}$ (soil 11), 12 DAS (soils 1, 3, 4, 13) and 14 DAS (soils 5, 8). General symptoms were as for experiment 1 but initial symptoms in different soils varied from general chlorosis of the plant to red colouration in the interveinal areas of $\mathrm{Zn}_{0}$ plants. Deficiency symptoms in plants grown in deficient soils developed rapidly and were seen at harvest in $Z_{1}$ plants of soils 1,3 and 13 but not in $\mathrm{Zn}_{2}$ plants. Plants from soil 10 had unusual symptoms from 9 DAS when primary leaves developed sharply defined interveinal chlorosis. These symptoms became slightly paler with each new leaf but were still present on all leaves at harvest. Growth of the plants from soil 10 was not obviously affected but the maximum yield was $79 \mathrm{~g}$ compared to yields of $87-110 \mathrm{~g}$ for other krasnozem soil types (11 and 12), and the response curve was very flat.

Infection of roots by VAM was low $(<8 \%)$ in all soils.

Prediction of growth response to applied $Z n$ by concentration in YFEL. Shoot fresh weight was increased by the application of $\mathrm{Zn}$ in 8 soils (Table 2). Soils $1,3,4,5,8,9,11$ and 13 had a $\mathrm{RY}$ for $\mathrm{Zn}_{0}$ treatments of $<0.9$ and were considered to be responsive to $\mathrm{Zn}$. The largest increases in fresh weight of shoots from $\mathrm{Zn}_{0}$ to $\mathrm{Zn}_{2}$ occurred in soils with the most severe deficiency symptoms (soils 1, 428\%; 3, 605\%; 4, 166\% and $13,154 \%$ ). Increases for the remaining responsive soils were $113-126 \%$. Apart from soil 10, all responsive soils showed deficiency symptoms. $\mathrm{Zn}_{1}$ treatments generally supplied sufficient $\mathrm{Zn}$ for maximum growth. Only soils 1 and 9 had a relative yield of less than 0.9 (RY of 0.82 and 0.89 , respectively) for this treatment. The critical $\mathrm{Zn}$ concentration (and standard error) determined by the 2 intersecting straight lines model was $10.1(0.5) \mathrm{mg} / \mathrm{kg}\left(r^{2}=0.33, P<0.01 ;\right.$ Fig. $\left.2 b\right)$.

Relationship between growth parameters and soil tests. The relationships between $\mathrm{RY}$ and the $\mathrm{Zn}$ concentration determined by soil solution, $0.002 \mathrm{~mol} / \mathrm{L}$ $\mathrm{CaCl}_{2}$ and $0.01 \mathrm{~mol} / \mathrm{L} \mathrm{CaCl}$ soil tests were characterised by a steep initial response, where large increases in $\mathrm{RY}$ were observed for small increases in the amount of $\mathrm{Zn}$ extracted (Table 2). For HCl, EDTA and DTPA extractants, the relationships between RY and soil test were poorly defined.

Because of the initial steepness of the RY/intensity relationships, the effect of buffer capacity was examined. When $\mathrm{Zn}$ concentration in YFEL for the $\mathrm{Zn}_{0}$ treatments was plotted against soil solution $\mathrm{Zn}$ (Fig. 3), it was apparent that at the same intensity (i.e. concentration in the soil solution), high buffer capacity soils supported higher YFEL $\mathrm{Zn}$ concentrations than low buffer capacity soils. From this relationship, the soils can be classified as having a high, medium or low buffer capacity using the following ranges of $\mathrm{BCI}$ : high, $\mathrm{BCI}>1.0$; medium, $\mathrm{BCI}$ $0.1-1.0$; low, $\mathrm{BCI}<0.1$. Three separate relationships, dependent on BCI, can be defined between YFEL $\mathrm{Zn}$ concentration and soil solution Zn (Fig. 3).

When soil solution $\mathrm{Zn}$ was combined with $\mathrm{BCI}$, both 
Table 2. Zn concentration in soils at planting, fresh weight (FW) of shoots, relative yield, and Zn concentration in YFEL for experiment 2

\begin{tabular}{|c|c|c|c|c|c|c|c|c|c|c|c|c|c|c|}
\hline \multirow{3}{*}{$\begin{array}{l}\text { Soil } \\
-1\end{array}$} & \multirow{3}{*}{$\begin{array}{c}\begin{array}{c}\mathrm{HCl} \\
(\mathrm{mg} / \mathrm{kg})\end{array} \\
0.24\end{array}$} & \multirow{3}{*}{$\begin{array}{c}\begin{array}{c}\text { EDTA } \\
(\mathrm{mg} / \mathrm{kg})\end{array} \\
0.13\end{array}$} & \multirow{3}{*}{$\begin{array}{r}\begin{array}{r}\text { DTPA } \\
(\mathrm{mg} / \mathrm{kg})\end{array} \\
0.07\end{array}$} & \multirow{3}{*}{$\begin{array}{c}\begin{array}{c}0.01 \mathrm{~mol} / \mathrm{L} \\
\mathrm{CaCl}_{2} \\
(\mathrm{mg} / \mathrm{kg})\end{array} \\
<0.005\end{array}$} & \multirow{3}{*}{$\begin{array}{c}0.002 \mathrm{~mol} / \mathrm{L} \\
\mathrm{CaCl}_{2} \\
(\mathrm{mg} / \mathrm{kg})\end{array}$} & \multirow{3}{*}{$\begin{array}{l}\text { Soil solution } \\
(\mu \mathrm{g} / \mathrm{L})\end{array}$} & \multirow{3}{*}{$\begin{array}{c}\mathrm{BCl} \\
(1000 \mathrm{~L} / \mathrm{kg}) \\
0.40\end{array}$} & \multicolumn{3}{|c|}{ FW of shoots } & \multirow{3}{*}{$\frac{\begin{array}{c}\text { Relative } \\
\text { yield } \\
\text { for } \mathrm{Zn}_{0}\end{array}}{0.23}$} & \multicolumn{3}{|c|}{ YFEL Zn } \\
\hline & & & & & & & & $\mathrm{Zn}_{0}$ & $\begin{array}{c}\mathrm{Zn}_{1} \\
(\mathrm{~g} / \mathrm{pot})\end{array}$ & $\mathrm{Zn}_{2}$ & & & $\underset{(\mathrm{mg} / \mathrm{kg}}{\mathrm{Zn}_{1}}$ & $\mathrm{gn}_{2}$ \\
\hline & & & & & & & & 16.3 & 57.2 & 69.6 & & 5.8 & 7.8 & 9.8 \\
\hline 2 & 0.13 & 0.11 & 0.06 & 0.027 & 0.008 & 3.1 & 0.04 & 65.9 & 65.7 & 65.8 & 1.00 & 9.5 & 23.7 & 32.2 \\
\hline 3 & 0.11 & 0.09 & 0.05 & $<0.005$ & $<0.005$ & 1.1 & 0.10 & 13.8 & 78.2 & 83.4 & 0.17 & 7.9 & 8.8 & 15.0 \\
\hline 4 & 0.06 & 0.04 & 0.02 & 0.014 & 0.005 & 0.6 & 0.09 & 43.8 & 72.7 & 72.9 & 0.60 & 9.3 & 28.9 & 41.4 \\
\hline 5 & 0.62 & 0.70 & 0.40 & $<0.005$ & $\ldots B$ & 2.4 & 0.26 & 57.4 & 66.2 & 67.4 & 0.85 & 8.8 & 20.3 & 24.2 \\
\hline $6^{\mathrm{A}}$ & 0.34 & 0.32 & 0.23 & 0.147 & 0.063 & 19.2 & 0.02 & 86.1 & 82.4 & 82.7 & 1.00 & 12.4 & 24.5 & 31.3 \\
\hline $7 \mathrm{~A}$ & 1.70 & 1.41 & 0.53 & 1.60 & 0.079 & 10.4 & 0.16 & 72.9 & 61.2 & 64.5 & 1.00 & 19.3 & 18.8 & 19.3 \\
\hline 8 & 0.69 & 0.82 & 0.44 & 0.006 & 0.017 & 7.1 & 0.10 & 77.8 & 89.4 & 97.3 & 0.80 & 10.3 & 15.2 & 21.3 \\
\hline 9 & 1.11 & 1.16 & 0.80 & 0.025 & 0.010 & 5.8 & 0.19 & 79.7 & 80.1 & 90.4 & 0.88 & 15.9 & 23.9 & 26.7 \\
\hline 10 & 1.54 & 0.89 & 0.73 & 0.006 & 0.005 & 0.9 & 1.71 & 75.1 & 78.4 & 79.3 & 0.95 & 12.9 & 16.8 & 21.8 \\
\hline 11 & 1.85 & 0.52 & 0.98 & 0.238 & 0.071 & 5.3 & 0.35 & 87.0 & 104.5 & 110.0 & 0.79 & 14.7 & 21.2 & 30.0 \\
\hline 12 & 6.58 & 3.78 & 2.89 & 0.021 & 0.017 & 1.7 & 3.87 & 94.8 & 92.4 & 90.2 & 1.00 & 23.0 & 26.9 & 27.5 \\
\hline 13 & 1.00 & 0.44 & 0.28 & $<0.005$ & $<0.005$ & 0.8 & 1.25 & 57.6 & 87.8 & 88.7 & 0.65 & 7.5 & 20.4 & 28.1 \\
\hline s.e. & 0.08 & 0.07 & 0.06 & 0.003 & 0.001 & 1.5 & & & & & & & & \\
\hline
\end{tabular}

factors were significant in explaining variation in the YFEL $\mathrm{Zn}$ concentration (Table 3), but the $r^{2}$ was low $(0.55)$. In multiple regressions of YFEL $\mathrm{Zn}$ concentration against soil tests, any of the intensity measurements (soil solution, $0.002 \mathrm{~mol} / \mathrm{L} \mathrm{CaCl}_{2}$, $0.01 \mathrm{~mol} / \mathrm{L} \mathrm{CaCl}_{2}$ ) significantly increased the variation in YFEL concentration accounted for by any quantity soil tests ( $\mathrm{HCl}$, EDTA and DTPA, Table 3). Quantity and intensity measurements together accounted for $78-90 \%$ of the variation in YFEL $\mathrm{Zn}$ concentration.

Soil solution $\mathrm{Zn}$ was significantly correlated with $0.002 \mathrm{~mol} / \mathrm{L} \mathrm{CaCl} 2-\mathrm{Zn}$ and with $0.01 \mathrm{~mol} / \mathrm{L} \mathrm{CaCl} \mathrm{Cl}_{2}-\mathrm{Zn}$ ( $r=0.75, P<0.01 ; r=0.62, P<0.05$, respectively) and the

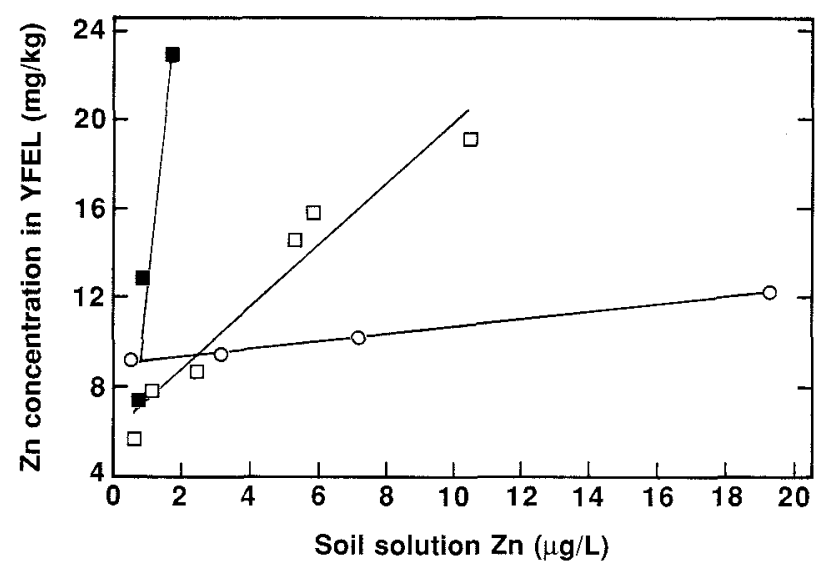

Fig. 3. Experiment 2. The relationship between the $\mathrm{Zn}$ concentration in YFEL of navy beans and soil solution $\mathrm{Zn}$. Buffer capacity ratings are low $(\bigcirc)$, medium( $(\square)$ and high $(\mathbf{\bullet})$.
$2 \mathrm{CaCl}_{2}$ methods were themselves significantly correlated $(r=0.95, P<0.001)$. BCI was highly correlated with $\mathrm{HCl}-$, EDTA - and DTPA-Zn $(r=0.90,0.83$ and 0.87 , respectively; $P<0.001)$. $\mathrm{HCl}-$, EDTA- and DTPA-Zn were correlated with each other $(r>0.95, P<0.001)$.

\section{Discussion}

Prediction of the $\mathrm{Zn}$ status of navy beans grown in the 13 soils of experiment 2 , using the critical $\mathrm{Zn}$ concentration derived in experiment 1 of $10.6 \mathrm{mg} / \mathrm{kg}$ in the YFEL, was correct for about $77 \%$ of samples. It would have incorrectly diagnosed plants from soil 2 as being $Z n$-deficient and plants from soils 9 and 11 as being $\mathrm{Zn}$-adequate. The YFEL $\mathrm{Zn}$ concentration in soil 8 for the $Z_{n_{0}}$ treatment was in the range of the standard error. The critical $\mathrm{Zn}$ concentrations in the YFEL determined in experiment 1 with 1 soil $(10.6 \mathrm{mg} / \mathrm{kg})$ and in experiment 2 with 13 soils $(10.1 \mathrm{mg} / \mathrm{kg})$ were not statistically different $(P<0.01)$, so that a critical $\mathrm{Zn}$ concentration range in the YFEL of Gallaroy navy beans can be defined as $10-11 \mathrm{mg} / \mathrm{kg}$. These data confirm the usefulness of young plant tissue as diagnostic tissue for $\mathrm{Zn}$ in plants, although the advantage of YFEL over whole tops was not as great as that reported by Reuter et al. (1972).

The critical $\mathrm{Zn}$ concentration range in the YFEL of $10-11 \mathrm{mg} / \mathrm{kg}$ for cv. Gallaroy is much lower than the range (i.e. $17-20 \mathrm{mg} / \mathrm{kg}$ ) reported by Wade and Bath (1985). Our critical $\mathrm{Zn}$ concentration in whole tops of $12.5 \mathrm{mg} / \mathrm{kg}$ is also less than the range of $18.2-20.2 \mathrm{mg} / \mathrm{kg}$ for 3 other navy bean cultivars (Leggett and Westermann 1986). However, in both of these papers 
Table 3. Coefficients of multiple regression of YFEL $\mathrm{Zn}$ concentration on measures of quantity

( $\mathrm{HCl}$, EDTA, DTPA), buffer capacity (BCI, buffer capacity index) and intensity

(soil solution, $0.002 \mathrm{~mol} / \mathrm{L} \mathrm{CaCl}_{2}, 0.01 \mathrm{~mol} / \mathrm{L} \mathrm{CaCl}_{2}$ )

VAF, variance accounted for

\begin{tabular}{|c|c|c|c|c|}
\hline $\begin{array}{l}\text { BCI parameter } \\
\text { or extractant }\end{array}$ & Coefficient & $\begin{array}{l}\text { Intensity } \\
\text { parameter }\end{array}$ & Coefficient & $\operatorname{VAF}(\%)$ \\
\hline $\mathrm{BCI}$ & $3.321 \pm 1.022^{*}$ & Soil solution & $0.492 \pm 0.209 *$ & 55 \\
\hline $\mathrm{HCl}$ & $2.470 \pm 0.410^{* * * * 4}$ & Soil solution & $0.355 \pm 0.132 *$ & 80 \\
\hline $\mathrm{HCl}$ & $2.173 \pm 0.385^{* \text { 米前 }}$ & $0.002 \mathrm{~mol} / \mathrm{L} \mathrm{CaCl} 2$ & $71.50 \pm 22.88 *$ & 83 \\
\hline $\mathrm{HCl}$ & $2.258 \pm 0.429 * * * *$ & $0.01 \mathrm{~mol} / \mathrm{L} \mathrm{CaCl}_{2}$ & $22.58 \pm 9.434 *$ & 78 \\
\hline EDTA & $4.297 \pm 0.687 * * *$ & Soil solution & $0.289 \pm 0.128^{*}$ & 81 \\
\hline EDTA & $4.002 \pm 0.501 * * *$ & $0.002 \mathrm{~mol} / \mathrm{L} \mathrm{CaCl} 2$ & $74.41 \pm 17.14 *$ & 90 \\
\hline EDTA & $4.262 \pm 0.503 * * *$ & $0.01 \mathrm{~mol} / \mathrm{L} \mathrm{CaCl}_{2}$ & $27.17 \pm 6.384 * *$ & 90 \\
\hline DTPA & $5.554 \pm 0.942 * * *$ & Soil solution & $0.337 \pm 0.134 *$ & 80 \\
\hline DTPA & $4.987 \pm 0.822$ **** & $0.002 \mathrm{~mol} / \mathrm{L} \mathrm{CaCl} 2$ & $73.60 \pm 21.57$ 米米 & 85 \\
\hline DTPA & $5.136 \pm 0.959 * * *$ & $0.01 \mathrm{~mol} / \mathrm{L} \mathrm{CaCl}_{2}$ & $22.39 \pm 9.320^{*}$ & 79 \\
\hline
\end{tabular}

the critical $\mathrm{Zn}$ concentrations were estimated from only 2 rates of $Z n$ application. Wade and Bath (1985) measured the $\mathrm{Zn}$ concentration in the laminae of the YFEL rather than the leaf, and Leggett and Westermann (1986) harvested the shoots after 73 days. Navy bean cultivars vary in their sensitivity to $\mathrm{Zn}$ deficiency. For example, the range of yield increases with $\mathrm{Zn}$ application in 6 navy bean cultivars was $143-210 \%$ (Leggett and Westermann 1986).

For these soils, which represent a very wide range of agriculturally significant soils, it was not possible to recommend a single soil extractant for prediction of $\mathrm{Zn}$ deficiency in navy beans. The relationship between relative yield and quantity measurements was not consistent, and all of the intensity measurements had a steep initial response. EDTA in combination with $0.01 \mathrm{~mol} / \mathrm{L} \mathrm{CaCl} \mathrm{Cl}_{2}$ explained the most variation $(90 \%)$ in $\mathrm{Zn}$ concentration of YFEL of the quantity/intensity combinations. $\mathrm{HCl}$ or DTPA and $0.01 \mathrm{~mol} / \mathrm{L} \mathrm{CaCl} 2$ explained about $80 \%$ of the variation. The $0.002 \mathrm{~mol} / \mathrm{L}$ or $0.01 \mathrm{~mol} / \mathrm{L} \mathrm{CaCl} \mathrm{Cl}_{2}$ solutions may be used as a more convenient extractant than soil solution for measurement of the soil $\mathrm{Zn}$ intensity. The use of $0.002 \mathrm{~mol} / \mathrm{L} \mathrm{CaCl} 2$ has the advantage of a higher correlation with soil solution $\mathrm{Zn}$ than $0.01 \mathrm{~mol} / \mathrm{L} \mathrm{CaCl} 2$ but with some soils (e.g. soil 5) it was difficult to obtain a clear filtrate in $0.002 \mathrm{~mol} / \mathrm{L} \mathrm{CaCl}$.

Absolute plant parameters such as nutrient content and nutrient concentration are more sensitive indicators of nutrient availability than relative parameters such as $\mathrm{RY}$. Of the absolute parameters, $\mathrm{Zn}$ concentrations in the YFEL were available for this experiment. For both YFEL $\mathrm{Zn}$ concentration and RY, it would be expected that at the same intensity, soils of high buffer capacity would have greater $\mathrm{Zn}$ availability than soils of low buffer capacity, because the former soils would maintain intensity despite the absorption of $\mathrm{Zn}$ from the soil solution by plant roots. A soil test which reflects $\mathrm{Zn}$ availability to the plant must therefore be a composite index combining both intensity and buffer capacity. The results of experiment 2 indicate that an intensity-based soil test (such as soil solution $\mathrm{Zn}$ or $0.002 \mathrm{~mol} / \mathrm{L} \mathrm{CaCl}$ ) requires an estimate of buffer capacity to estimate $\mathrm{Zn}$ availability adequately, whereas soil tests which primarily estimate quantity (e.g. $\mathrm{HCl}-\mathrm{Zn}$ ) require the addition of an intensity estimate. This situation is analogous to the evaluation of soil tests for $\mathrm{P}$, and either of 2 approaches may be adopted. One can either combine estimates of intensity and quantity or buffer capacity in multiple regression equations to describe nutrient availability as suggested by Moody and Barry (1983), or find an empirical soil test which is highly correlated with nutrient availability in that particular situation and which gives a composite measure of quantity and intensity (eg. Holford and Crocker 1988). As BCI was significantly correlated $(P<0.01)$ with the quantity soil tests ( $\mathrm{HCl}, \mathrm{EDTA}$ and DTPA), the quantity soil tests may be used instead of BCI (Table 3) Perhaps narrower soil/extracting solution ratios and lower extractant concentrations for the quantity tests would improve the correlation of these empirical tests with $\mathrm{Zn}$ availability..

These data confirm the conclusions of Tiller et al. (1972) for wheat and clover and McGrath et al. (1985) for clover that consideration of the intensity of $\mathrm{Zn}$ in the soil is required to develop a soil test that will predict $\mathrm{Zn}$ responsiveness over a range of soil types.

\section{Conclusions}

A critical concentration of $10-11 \mathrm{mg} / \mathrm{kg}$ in the YFEL can be used to diagnose the $\mathrm{Zn}$ status of Gallaroy navy 
beans. None of the soil tests assessed were able to predict $\mathrm{Zn}$ deficiency when considered alone. However, combining EDTA-Zn with $0.01 \mathrm{~mol} / \mathrm{L} \mathrm{CaCl} \mathrm{Cl}_{2}-\mathrm{Zn}$ in a multiple regression accounted for $90 \%$ of the variation in $\mathrm{Zn}$ concentration of the YFEL. If 4.3 (EDTA-Zn) +27.2 (0.01 $\mathrm{mol} / \mathrm{L} \mathrm{CaCl} 2-\mathrm{Zn}$ ) is less than 2.7 (from Table 3), then it may be inferred that a $\mathrm{Zn}$ deficiency in Gallaroy is likely (i.e. the predicted YFEL $\mathrm{Zn}$ concentration will be less than the critical concentration of $10 \mathrm{mg} / \mathrm{kg}$ ). The coefficients of this equation need to be verified under field conditions.

\section{Acknowledgments}

The senior author completed this research while on Study Leave from the Queensland Department of Primary Industries. We thank $\mathrm{Mr}$ W. J. Simmons and Mr K. Snowball for technical advice and Mr P. W. Moody for helpful comments on a draft of the manuscript.

\section{References}

Abbott, L. K., and Robson, A. D. (1981). Infectivity and effectiveness of vesicular arbuscular mycorrhizal fungi: effect of inoculum type. Australian Journal of Agricultural Research 32, 631-9.

Aitken, R. L., and Outhwaite, R. J. (1987). A modified centrifuge apparatus for extracting soil solution. Communications in Soil Science and Plant Analysis 18, $1041-7$.

Allan, J. E. (1961). The determination of zinc in agricultural materials by atomic absorption spectrophotometry. The Analyst 86, 531-4.

Armour, J. D., Ritchie, G. S. P., and Robson, A. D. (1989). Changes with time in the availability of soil applied zinc to navy beans and in the chemical extraction of zinc from soils. Australian Journal of Soil Research 27, 699-710.

Boawn, L. C., Rasmussen, P. E., and Brown, J. W. (1969). Relationship between tissue zinc and maturity period of field beans. Agronomy Journal 61, 49-51.

Brennan, R. F. (1990). Reaction of zinc with soil affecting its availability to subterranean clover. Il. Effect of soil properties on the relative effectiveness of applied zinc. Australian Journal of Soil Research 28, 303-10.

Brouwer, H. W., Stevens, G. R., and Fletcher, J. G. (1981). Differential varietal response to zinc foliar sprays in navy beans (Phaseolus vulgaris). Queensland Journal of Agriculture and Animal Sciences 38, 179-85.

Cox, F. R., and Kamprath, E. J. (1972). Micronutrients soil tests. In 'Micronutrients in Agriculture.' pp. 308-13. (Soil Science Society America: Madison.)

Fujii, R., and Corey, R. B. (1986). Estimation of isotopically exchangeable cadmium and zinc in soils. Soil Science Society of America Journal 50, 306-8.

Griffiths, D. A., and Miller, A. J. (1973). Hyperbolic regression-a model based on two-phase piecewise linear regression with a smooth transition between regimes. Commmunications in Statistics 2, 561-9.
Hewitt, E. J. (1952). Sand and water culture methods used in the study of plant nutrition. Commonwealth Bureau of Horticulture and Plantation Crops, Technical Communication No. 22.

Holford, I. C. R., and Crocker, G. J. (1988). Efficacy of various soil phosphate tests for predicting phosphate responsiveness and requirements of clover pastures on acidic Tableland soils. Australian Journal of Soil Research 26, 479-88.

Johnson, C. M., and Ulrich, A. (1959). Analytical methods for use in plant analysis. California Agricultural Experiment Station Bulletin No. 766.

Leggett, G. E., and Westermann, D. T. (1986). Effects of corn, sugarbeets and fallow on zinc availability in subsequent crops. Soil Science Society of America Journal 50, 963-8.

Lindsay, W. L., and Norvell, W. A. (1978). Development of a DTPA soil test for zinc, iron, manganese and copper. Soil Science Society of America Journal 42, 421-8.

McGrath, S. P., Sanders, J. R., and Adams, J. M. (1985). Comparison of soil solution and chemical extractants to estimate metal availability to plants. Journal of the Science of Food and Agriculture 36, 532-3.

Moody, P. M., and Barry, G. A. (1983). The use of buffer capacity and intensity measurements for the assessment of phosphorus status of soils. In 'Proceedings Third International Congress on Phosphorus Compounds, Brussels, October 4-6, 1983'. pp 209-15. (IMPHOS: Casablanca, Morocco.)

Moraghan, J. T. (1984). Differential response of five species to phosphorus and zinc fertilisers. Communications in Soil Science and Plant Analysis 15, 437-47.

Mugwira, L. M., and Knezek, B. D. (1971). Growth and plant zinc distribution in 2 navy bean varieties fertilised with zinc. Communications in Soil Science and Plant Analysis 2, 407-13.

Northcote, K. H. (1971). 'A Factual Key for the Recognition of Australian Soils.' 3rd. Edn. (Rellim Technical Publications: Glenside, S. Aust.)

Reuter, D. J., Loneragan, J. F., Robson, A. D., and Plaskett, D. (1982). Zinc in subterranean clover (Trifolium subterranean L. cv. Seaton Park) 1. Effects of zinc supply on distribution of zinc and dry weight among plant parts. Australian Journal of Agricultural Research 33, 989-99.

Tiller, K. G., Honeysett, J. L., and DeVries, M. P. C. (1972). Soil zinc and its uptake by plants II. Soil chemistry in relation to prediction of availability. Australian Journal of Soil Research 10, 165-82.

Viets, F. G., Boawn, L. C., and Crawford, C. L. (1954). Zinc content of bean plants in relation to deficiency symptoms and yield. Plant Physiology 29, 76-79.

Wade, L. J., and Bath, S. J. (1985). Zinc deficiency in navy beans in the Dawson-Callide. 2. Response to zinc application in the field. Queensland Journal of Agriculture and Animal Sciences 42, 63-9. 